\title{
The IgH locus 3' cis-regulatory super-enhancer co-opts AID for allelic transvection
}

\author{
Sandrine Le Noir ${ }^{1, *}$, Brice Laffleur ${ }^{1, *}$, Claire Carrion $^{1}$, Armand Garot $^{1}$, Sandrine \\ Lecardeur ${ }^{1}$, Eric Pinaud ${ }^{1}$, Yves Denizot ${ }^{1}$, Jane Skok ${ }^{2}$ and Michel Cogné ${ }^{1}$ \\ ${ }^{1}$ UMR 7276 CNRS and Université de Limoges: Contrôle de la Réponse Immune B et Lymphoprolifération, Limoges, France \\ 2 Department of Pathology, New York University School of Medicine, New York, NY, USA \\ * These authors have contributed equally to this work \\ Correspondence to: Michel Cogné, email: cogne@unilim.fr \\ Keywords: super-enhancer; alleles; transvection; nuclear positioning; gene regulation \\ Received: December 20,2016 Accepted: January 01,2017 Published: Janaury 10, 2017
}

\section{ABSTRACT}

Immunoglobulin heavy chain $(I g H)$ alleles have ambivalent relationships: they feature both allelic exclusion, ensuring monoallelic expression of a single immunoglobulin (Ig) allele, and frequent inter-allelic class-switch recombination (CSR) reassembling genes from both alleles. The $I g H$ locus $3^{\prime}$ regulatory region ( $\left.3^{\prime} R R\right)$ includes several transcriptional cis-enhancers promoting activation-induced cytidine deaminase (AID)-dependent somatic hypermutation (SHM) and CSR, and altogether behaves as a strong super-enhancer. It can also promote deregulated expression of translocated oncogenes during lymphomagenesis. Besides these rare, illegitimate and pathogenic interactions, we now show that under physiological conditions, the 3'RR super-enhancer supports not only legitimate cis- , but also trans-recruitment of AID, contributing to $I g H$ inter-allelic proximity and enabling the super-enhancer on one allele to stimulate biallelic SHM and CSR. Such inter-allelic activating interactions define transvection, a phenomenon well-known in drosophila but rarely observed in mammalian cells, now appearing as a unique feature of the IgH 3'RR super-enhancer.

\section{INTRODUCTION}

Interactions and co-localization of non-homologous genes are favored by super-enhancers, i.e. major cisregulatory elements controlling key cell identity genes [14]. In B-cells, the specific and frequent co-localization of immunoglobulin heavy chain $(I g H)$ genes, Ig $\kappa$ light chain genes $(I g \kappa)$ and $\mathrm{J}$-chain genes $(I g J)$ has been reported at all stages of B-cell differentiation including plasma cells where high expression of these loci often involves the same transcription factories and a nuclear organization that may optimize the nuclear export of their transcripts and further translation $[1,3,4]$. Functional interactions between those co-localized non-homologous genes occur at the level of transcription, with the $3^{\prime} \mathrm{E}$ e enhancer positively influencing $I g H$ transcription [3], but such effects were not evaluated between alleles of each locus.

Stimulatory interactions between homologous paired alleles, defining transvection, are well known in drosophila [5], but rarely observed in mammals except in pathologic or artificial settings. For example, transvection was documented between an $\operatorname{IgH}$-translocated CCND1 gene and its non-translocated counterpart [6]. Manipulating the mouse genome also yielded transvection from a mutant paternal and expressed Igfr2 allele which triggered expression of an otherwise silent maternal allele [7]. Inhibitory trans-regulation, supporting allelic exclusion, is by contrast frequent in mammalian physiology. Regarding Ig genes, ordered V(D)J recombination initiates allelic exclusion during early B cell development, when a functional rearrangement shuts off accessibility of the second allele, which correlates with modified epigenetic marks, interactions of $\operatorname{IgH} / \operatorname{Ig} \kappa$ loci, and changes in nuclear location $[8,9]$.

In mature activated B-cells, localization close to the nuclear periphery and co-localization with $I g \kappa$ and $I g J$ genes preferentially mark the functionally rearranged $\mathrm{IgH}$ allele [3]. However, inter-allelic contacts are also repeatedly identified in $3 \mathrm{C}, 4 \mathrm{C}$, and $\mathrm{FISH}-3 \mathrm{D}$ [3, 9, 10]. In parallel, it is noticeable that both transcription and AID-dependent $I g H$ changes such as class switch recombination (CSR) and somatic hypermutation (SHM) 
usually affect both productive and non-productive alleles at similar levels $[9,11,12]$.

In the $\operatorname{IgH}$ locus, the role of the 3' regulatory region ( $\left.3^{\prime} \mathrm{RR}\right)$ enhancers goes beyond transcription and also features recruitment of AID for CSR, SHM or deletional silencing of constant genes through locus suicide recombination [13-17]. The 3 'RR super-enhancer features a high density of individual enhancers [15], eRNA transcription $[13,18]$, regulation by long noncoding RNA [4], active chromatin marks and the ability to promote higher-order chromosomal structures [19]. Its polymorphisms influence susceptibility to immune disorders, while it endows transgenes with B-cell specific expression and can also deregulate oncogenes [20-23]. As any cis-regulatory element, the 3 'RR controls covalently linked genes within a legitimate territory bounded by insulators, and even the deregulation of oncogenes secondary to translocation falls into bona fide "cis" effects. It is by contrast unclear whether the gene co-localization observed in B-cells has functional implications in trans.

In this regard, while illegitimate off-target CSR-like junctions with non $I g$ genes remain exceptional during AID expression, legitimate junctions repairing CSR breaks are known to occur actively in both cis and trans [24-27]. Promiscuous trans-CSR junctions strongly suggest that $\mathrm{IgH}$ biallelic co-localization has functional implications at stages where proximity might secure legitimate synapsis between concomitantly generated biallelic DNA breaks. In order to explore whether these functional interactions precede trans-CSR, we thus searched for inter-allelic stimulatory interactions reminiscent to transvection, and witnessed pairing between homologous and legitimate AID target alleles. Since the 3 'RR is a regulator of both long-range interactions and AID recruitment, we considered that inter-allelic proximity may yield legitimate effects in trans and in the absence of covalent linkage. Here we indeed demonstrate 3'RR-dependent IgH transinteractions in B-cells with either additional copies of the 3'RR linked to transgenes or, by contrast, with homozygous or hemizygous loss of the 3 'RR. The latter configuration also reveals the ability of the 3'RR superenhancer to yield DNA accessibility and recruit AID not only in cis but also in trans.

\section{RESULTS}

\section{3'RR-dependent interactions of $I g H$ transgenes with of endogenous $\mathrm{IgH}$ genes}

$\operatorname{IgH}$-Igא inter-chromosomic pairing has been shown to occur at all stages of B-cell differentiation (except pro-B), while $\operatorname{IgH}-\operatorname{IgH}$ inter-allelic interactions were evaluated during $\mathrm{V}(\mathrm{D}) \mathrm{J}$ recombination in developing B-cells [10] and plasma cells [3]. We checked and validated that pairing of $\operatorname{IgH}$ alleles can also be detected by $3 \mathrm{D}$ FISH in mature resting and in vitro activated B-cells (Figure 1A).

To determine whether pairing of homologous $\mathrm{IgH}$ sequences depends upon the chromosomal context, we analyzed mice which carry an $\operatorname{IgH}$ transgene either as one copy on chromosome 7 (mouse line 820) or 3 copies on chromosome 4 (mouse line 995). This large $\operatorname{IgH}$ transgene included the $\operatorname{IgH} 3$ 'RR (Figure 1B) [28]. In primary B-cells cultured in vitro (after $48 \mathrm{~h}$ anti-CD40 + IL-4 stimulation of splenic cells from the 820 strain), we observed frequent pairing of the endogenous $\operatorname{IgH}$ locus with the $I g H$ transgene. Pairing with the transgene reached a higher level (because there are two copies of the endogenous alleles with which it can pair) and competed with pairing of endogenous $\operatorname{IgH}$ alleles (Figures 1C and 1D). Similar results were obtained with cells from the second (995) transgenic mouse strain (Figures 1C and 1D). Together these experiments demonstrate that homologous $\operatorname{IgH}$ alleles or transgenes pair independent of chromosomal context.

\section{The 3' enhancer is required for pairing of an $\operatorname{IgH}$ transgene with the endogenous locus}

We next examined splenic B cells from $820 \Delta$ mice, which bear the 820 transgene after cre-mediated deletion of the entire 3'RR [28]. Consistent with previous analyses, we observed no cell surface expression of Ig encoded by the rearranged transgene in activated splenic $\mathrm{B}$ cells under switching conditions (Figure S1A). Further, the $820 \Delta$ cells expressed 3-fold less transgenic germline transcripts compared to 820 cells (Figure S1B). Importantly by comparison to the parental 820 strain cells, pairing of the mutant transgene with endogenous $I g H$ alleles was clearly reduced, while pairing between both endogenous $I g H$ alleles was restored to normal levels (Figure 1C). Thus, the ability of an $\operatorname{IgH}$ transgene to pair with the homologous endogenous locus strongly depends on its inclusion of the 3'RR.

\section{3'RR-dependent nuclear positioning of endogenous $\mathrm{IgH}$ loci}

To evaluate whether inter-allelic pairing of endogenous $\operatorname{Ig} H$ loci also relied on the $3^{\prime} \mathrm{RR}$, inter- $\operatorname{Ig} H$ distance was compared by 3D-FISH in $w t, \Delta 3^{\prime} \mathrm{RR}^{\mathrm{a} /}$ $w t^{\mathrm{b}}$ and homozygous $\Delta 3^{\prime} \mathrm{RR}^{\mathrm{a}} / \Delta 3^{\prime} \mathrm{RR}^{\mathrm{a}}$ in vitro activated B-cells (72h with LPS) (Figures 2A and 2B). As for close inter-allelic interactions $\leq 1 \mu \mathrm{m}$, none was detectable in $\Delta 3$ 'RR cells; they by contrast showed up in heterozygous cells, with a single 3 'RR being sufficient to bring both $I g H$ alleles into contact as in $w t$ cells, albeit at a lower frequency (Figure 2C). In addition, the distribution of the $I g H$ - IgH distance was clearly shifted toward increased 
distances for homozygous $\Delta 3^{\prime} \mathrm{RR}$ B-cells compared to $w t$ $(p=0.037)$ and $\Delta 3^{\prime} \mathrm{RR}^{\mathrm{a}} / w t^{\mathrm{b}}(p=0.024)$ (Figure $\left.2 \mathrm{D}\right)$. A control experiment with a distant non- $I g H$ probe from the same chromosome 12 showed no variation in the interchromosomal distance, demonstrating that effects of the 3'RR deletion do not extend beyond the $I g H$ locus (Figure 2E).

We also generated heterozygous $\Delta 3^{\prime} \mathrm{RR} / \Delta \mathrm{E} \mu$ mice lacking the 3'RR on one allele and $\mathrm{E} \mu$ on the other (Figure 2F), thereby suppressing known cis-interactions between these elements [19] in order to check whether inter-allelic interactions were still detectable in such conditions. 3C experiments in in vitro activated B-cells (72h with LPS) revealed persistent inter-allelic interactions, with $\mathrm{E} \mu$ from allele 1 contacting the 3 'RR from allele 2. Parallel controls monitored the lack of any interaction with the unrelated calreticulin gene (as described in [19] (Figure 1G)).

Taken together these observations show a 3'RRdependent inter-allelic interaction between $\operatorname{IgH}$ loci in mature B-cells, which might participate in the function of the super-enhancer.

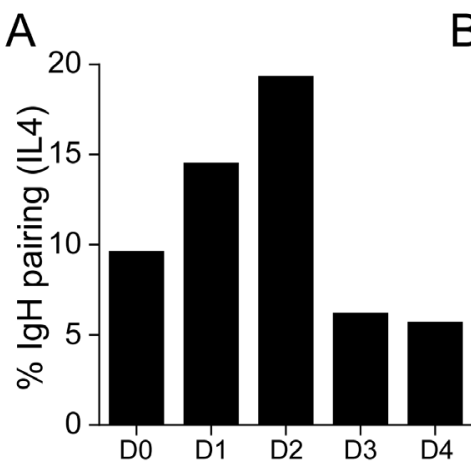

B Allele $w t$

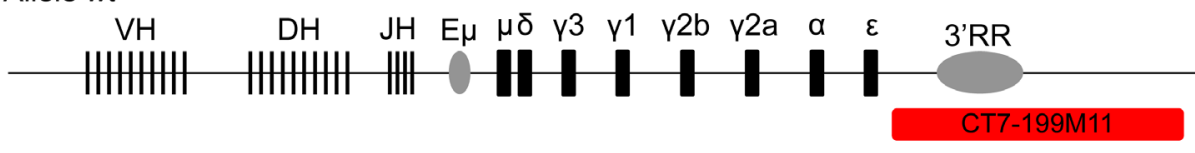

Transgene 820/995

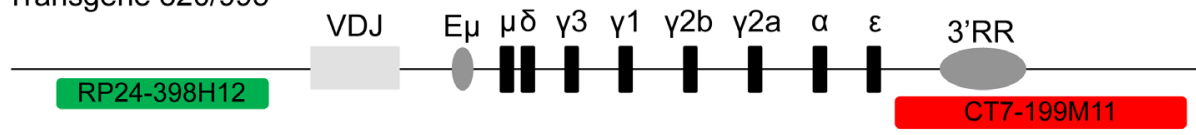

Transgene 820 $\Delta$ 3'RR
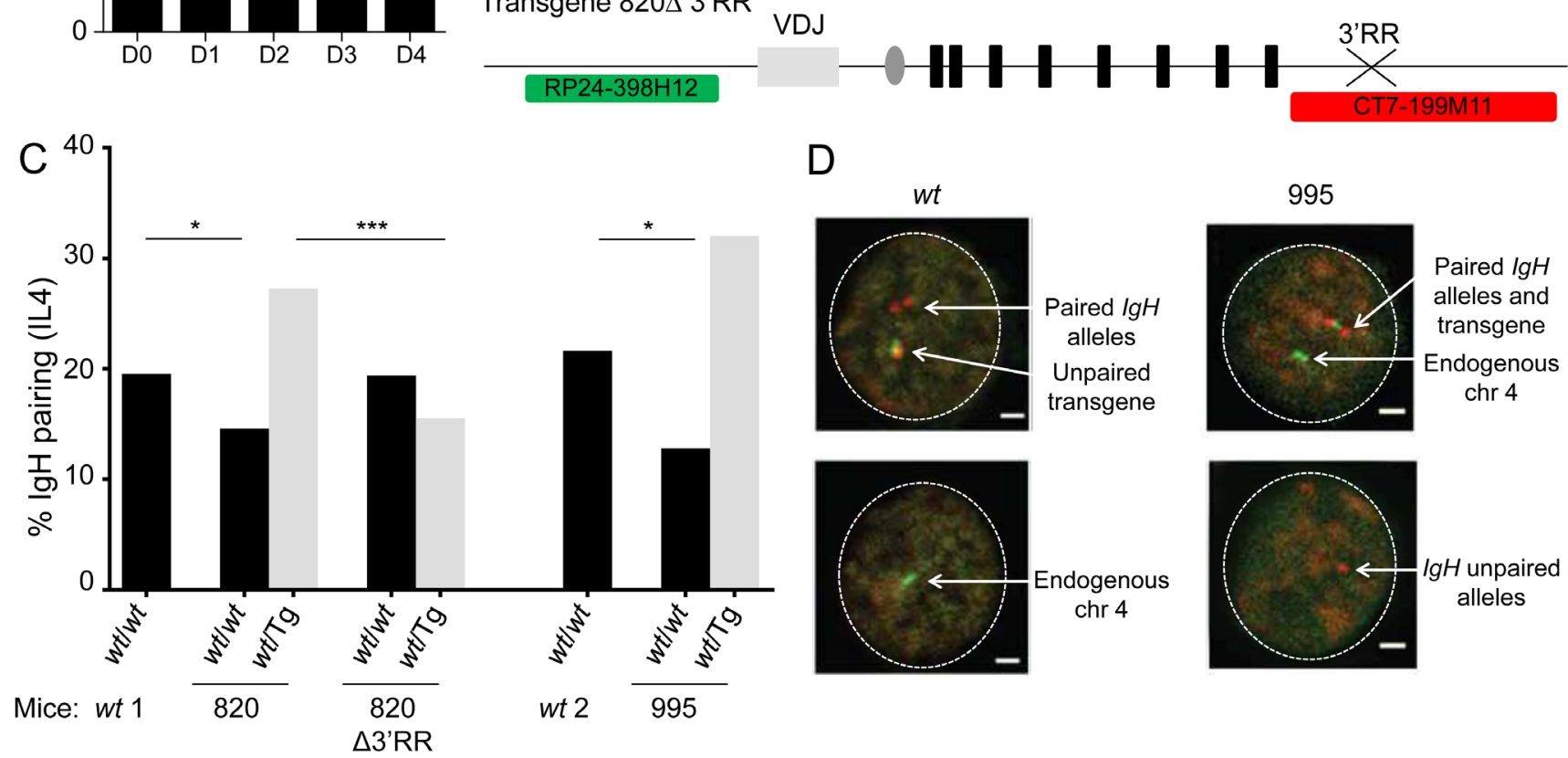

Paired $\lg H$

alleles and transgene Endogenous chr 4
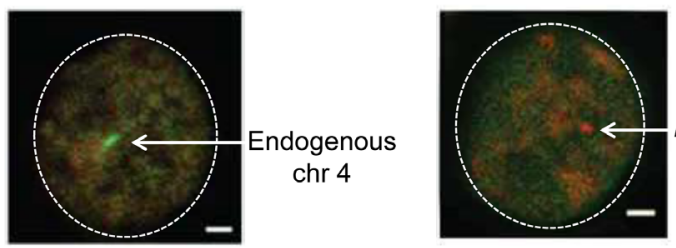

IgH unpaired alleles

Figure 1: 3'RR dependent $\boldsymbol{I g H}$ pairing in wt and transgenic B-cells. A. Kinetic of $I g H$ alleles pairing in in vitro activated $w t$ B-cells. Wt B splenocytes were stimulated 4 days in vitro with anti-CD40 + IL4 and IgH localization was studied by $3 \mathrm{D}$ FISH. IgH pairing (distance $\leq 1 \mu \mathrm{m}$ ) was quantified in resting (day 0) and activated B cells (D1, D2, D3, D4). Bars represent \% of pairing from 2 experiments with at least 585 cells analyzed. B. Schematic representation of alleles and probes used for 3D FISH experiments (not scaled). Wt alleles contain all V(D)J genes, constant genes and 3'RR, transgenes include a rearranged VDJ gene, constant genes and 3'RR (820 and 995 transgenes) or not ( $820 \Delta$ transgene). Probes are specific for $\operatorname{IgH}(\mathrm{CT} 7-199 \mathrm{M} 11$, red) or for transgene integration site (RP24-398H12, green, chromosome 4). C. IgH pairing in in vitro activated B lymphocytes. Cells were analyzed at day 2 and $\operatorname{IgH}$ pairing (distance $\leq 1 \mu \mathrm{m})$ between $w t$ and $w t$ alleles (black) or between $w t$ and transgenic alleles (grey) were quantified by 3D FISH. In a first set of experiments $w t$ cells (wt1) were compared to 820 and $820 \Delta$ transgenic cells and in a separated experiment $w t$ cells (wt2) were compared to 995 transgenic cells. Bars represent \% of pairing from 2 experiments, with at least 50 cells per group. DNA probes used were BAC CT7-199M11 for 3' IgH and BAC RP24-221C18 close to the insertion site of the $I g H$ transgene on chromosome 7 or BAC RP24-398H12, which is located adjacent to the insertion site of the $I g H$ transgene on chromosome 4. Fisher exact test for significance. D. Representative nuclei from 3D FISH experiments on in vitro activated B-cells (day 2). Examples of pairing between endogenous $I g H$ alleles in $w t$ cells and between transgene and $I g H$ alleles in 995 transgenic cells are shown. IgH loci are in red, transgene and endogenous chromosome 4 are in green. Scale bar: $1 \mu \mathrm{m}$. 
A

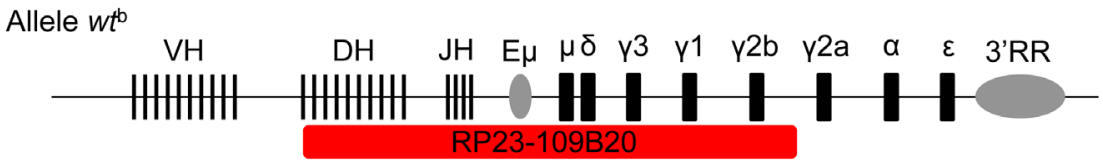

B

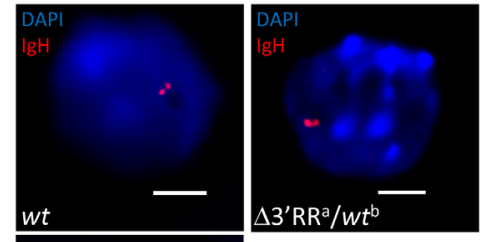

Allele $\Delta 3^{\prime} R^{a}$

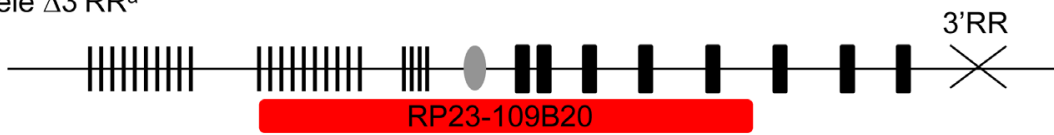

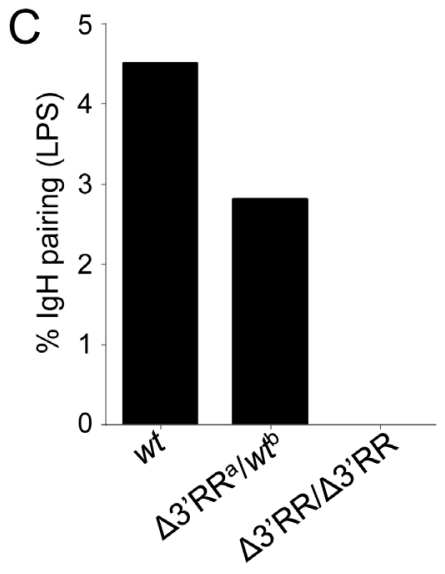

$\mathrm{F}$
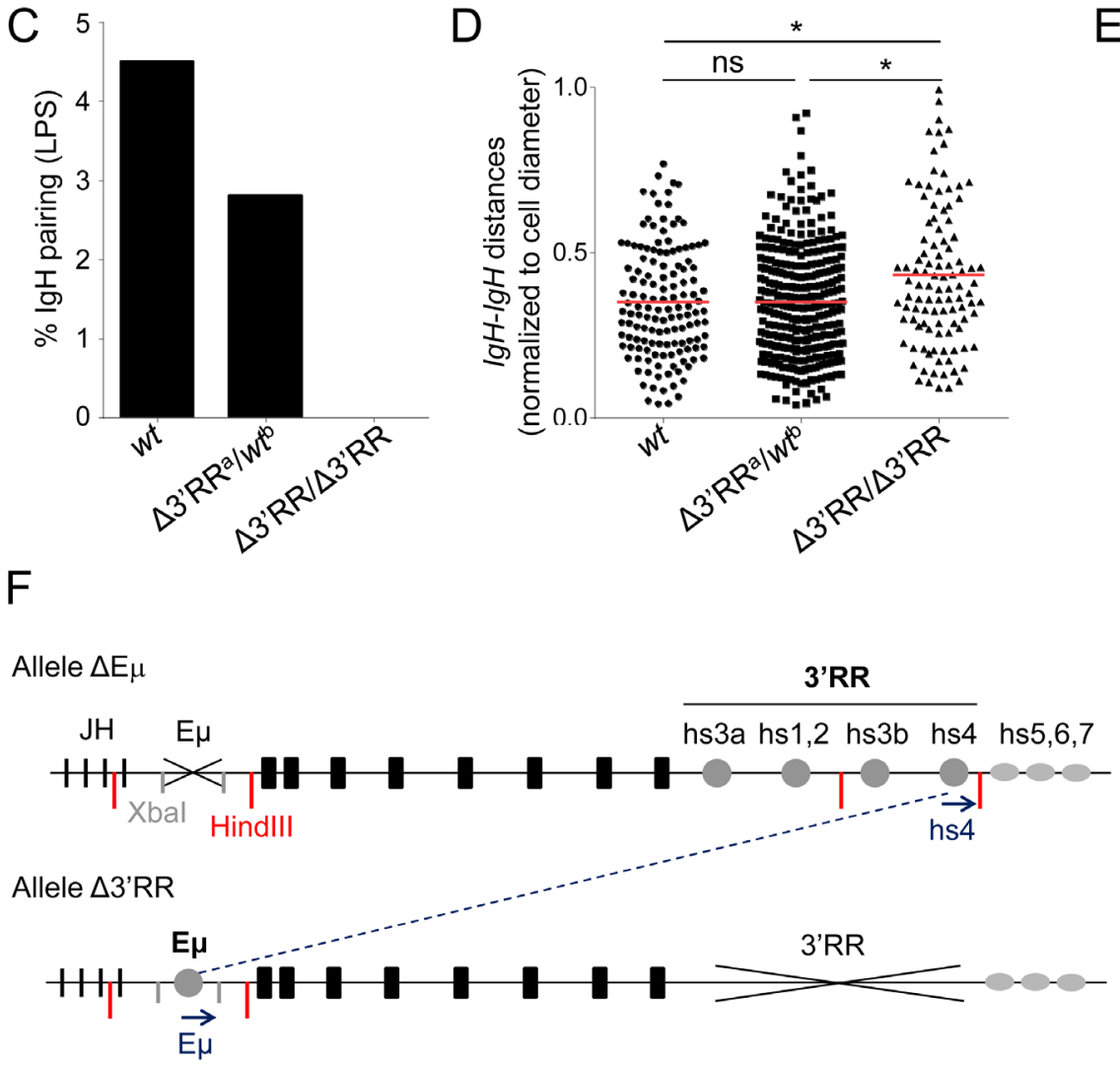
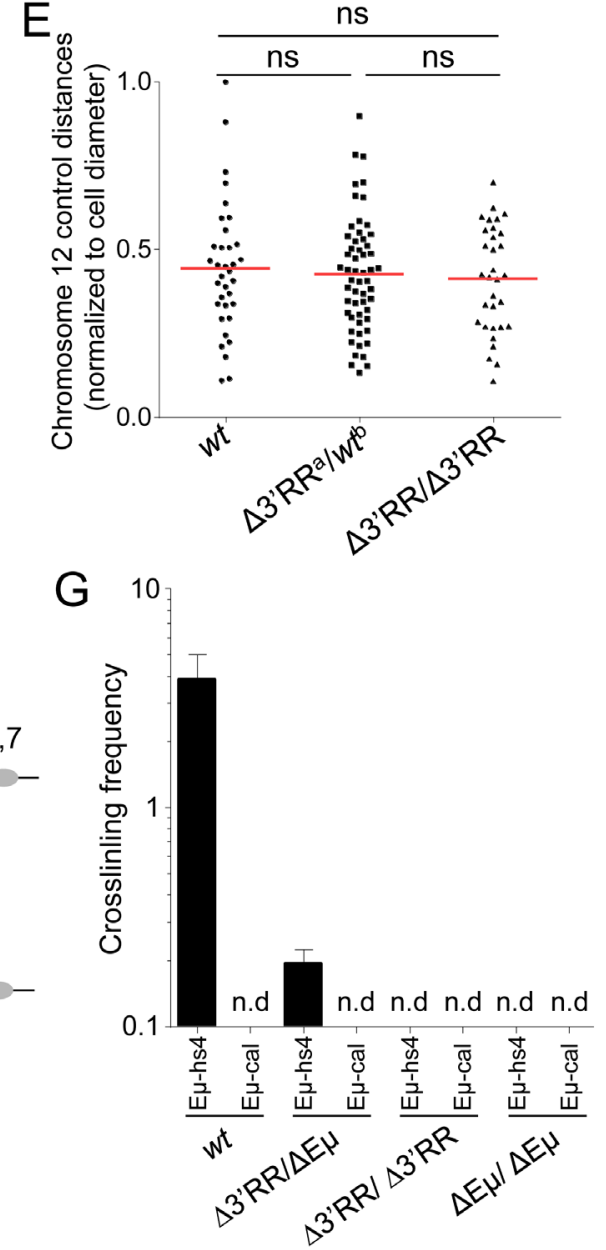

Figure 2: 3' RR-dependent $I g H$ inter-allelic interactions in $w t$, 3'RR hemizygous and 3'RR-deficient B cells. A. Schematic representation of $I g H$ alleles and probe (RP23-109B20, red) used for 3D FISH experiments (not scaled). $W t^{b}$ allele includes the $3^{\prime}$ RR, contrary to the $\Delta 3^{\prime}{ }^{\prime} R^{a}$ allele. B. Representative nuclei from 3D FISH experiments on in vitro LPS activated B-cells (day 3). Examples of pairing observed in $w t$ and $\Delta 3^{\prime} \mathrm{RR}^{\mathrm{a} /} w t^{\mathrm{b}}$ cells, $\Delta 3^{\prime} \mathrm{RR} / \Delta 3^{\prime} \mathrm{RR}$ failed to pair their $\operatorname{Ig} H$ alleles. DAPI is in blue, $I g H$ loci are in red. Scale bars: $4 \mu \mathrm{m}$. C. $I g H$ pairing in in vitro LPS activated B lymphocytes. Cells were analyzed at day 3 and $I g H$ pairing (distance $\leq 1 \mu \mathrm{m})$ between alleles was quantified by 3D FISH. Bars represent $\%$ of pairing from at least 2 experiments, corresponding to $138(w t), 107\left(\Delta 3^{\prime}\right.$ RR) and $324\left(\Delta 3^{\prime} R^{a} / w t^{b}\right)$ cells analyzed. D. Distribution of IgH inter-allelic distance in activated B-cells (with normalization according to cell diameter) from $w t, \Delta 3^{\prime} R R$ and $\Delta 3^{\prime} R^{a} / w t^{b}$ cells are shown (from the same cells as in $2 \mathrm{C}$ ). Mean is shown and KS test for significance. E. Distribution of inter-allelic distance (with normalization according to cell diameter) analyzed for a non- $I g H$ chromosome 12 locus (probe RP23-436M24) in activated B-cells from $w t(n=35), \Delta 3^{\prime} \mathrm{RR}(n=32)$ and $\Delta 3^{\prime} \mathrm{RR} / w t(n=56)$. ( $>2$ experiments with $>3$ mice per group). Mean is shown and KS test for significance. F. Schematic representation of $\operatorname{Ig} H \Delta \mathrm{E} \mu$ and $\Delta 3^{\prime} \mathrm{RR}$ alleles used for $3 \mathrm{C}$ experiments. Primers (blue arrows), XbaI (grey) and HindII (red) restriction sites are shown (not to scale). G. Relative inter-allelic interactions between $\operatorname{IgH}$ alleles determined by $3 \mathrm{C}$ experiments. E $\mu$-hs 4 or E $\mu$-calreticulin (E $\mu$-cal) $3 \mathrm{C}$ crosslinking frequencies for $w t, \Delta 3^{\prime} \mathrm{RR} / \Delta 3^{\prime} \mathrm{RR}, \Delta \mathrm{E} \mu / \Delta \mathrm{E} \mu$ and double heterozygous $\Delta 3^{\prime} \mathrm{RR} / \Delta \mathrm{E} \mu$ mice were determined from in vitro LPS activated B-cells ( 2 experiments with $\geq 3$ mice per group). Mean is shown $+/$ - s.e.m. (n.d., non-detected). 
Trans-activation by the $w t^{\mathrm{b}}$ allele functional 3'RR during CSR

We explored if proximity and 3'RR trans-activation might support CSR on the second allele. Homozygous 3'RR deletions suppress CSR-accessibility of downstream switch (S) regions but have no effect on $\mathrm{S} \mu$ (and barely any on S $\gamma 1)[17,29]$. This is partly rescued by heterozygosity, where trans-CSR is maintained and joins
A
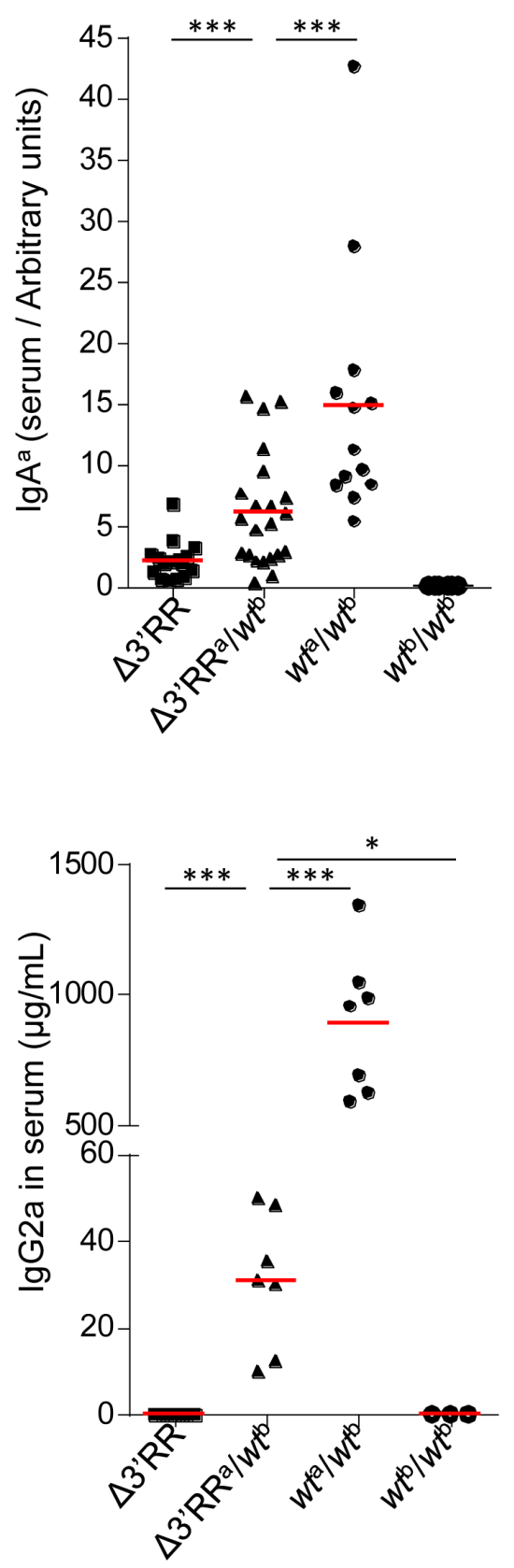

B
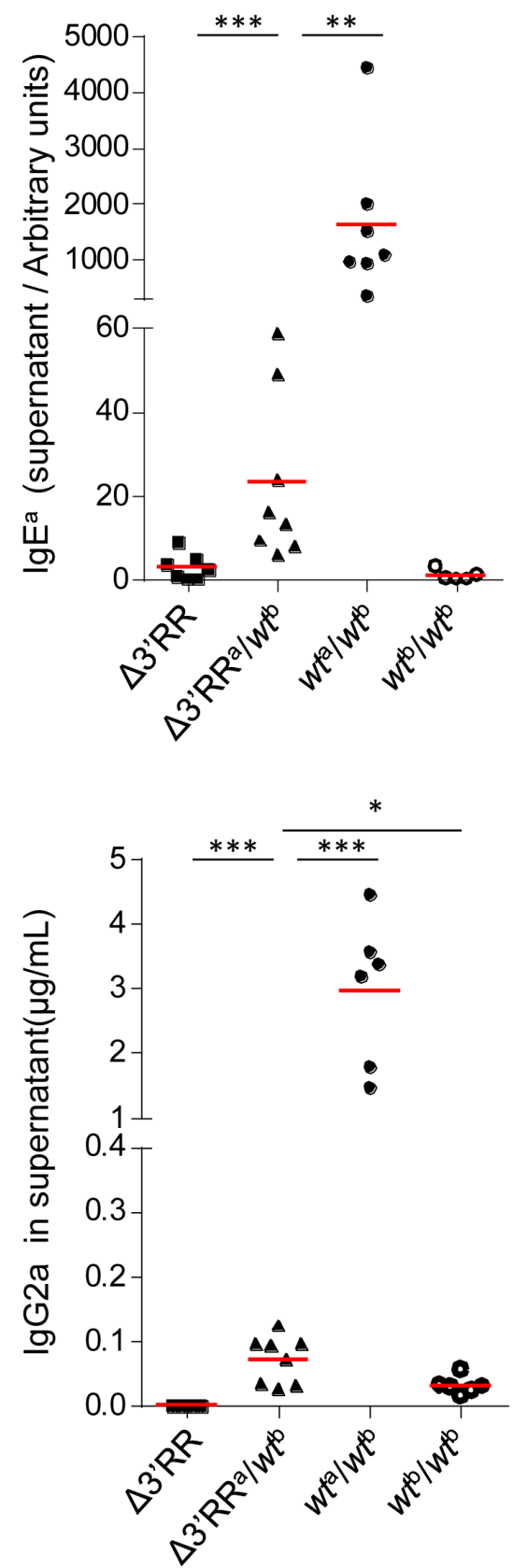

C
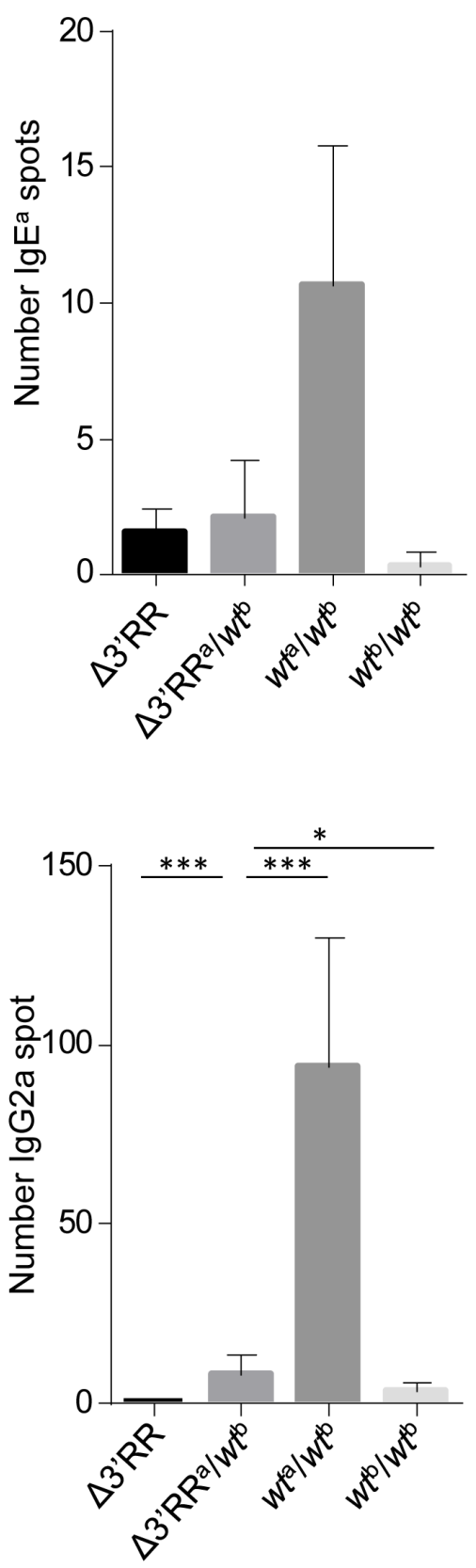

Figure 3: The 3'RR partially rescues CSR in trans on a 3'RR-cis-deficient $\operatorname{Ig} H$ allele. A. In vivo $\operatorname{Ig}^{\prime}{ }^{a}$ allele $\operatorname{CSR}^{\prime}$ in $\Delta 3^{\prime} \mathbf{R R}^{\mathrm{a}}$ $w t^{\mathrm{b}}$ mice: IgG2a (top) and Ig $\mathrm{A}^{\mathrm{a}}$ (bottom) serum levels from homozygous $\Delta 3^{\prime} \mathrm{RR}, \Delta 3^{\prime} \mathrm{RR}^{\mathrm{a}} / w t^{\mathrm{b}}$, $w t^{\mathrm{ab}}$ and $w t^{\mathrm{b} / \mathrm{b}}$ mice. Each point represents one mouse, mean is shown ( $\geq 3$ independent experiments). Mann-Whitney test for significance. B. In vitro Ig $H^{\mathrm{a}}$ allele CSR in $\Delta 3^{\prime} \mathrm{RR}^{\mathrm{a}} / w t^{\mathrm{b}}$ cells: IgG2a (top) and IgE (bottom) levels in supernatant from $\Delta 3^{\prime} R R, \Delta 3^{\prime} R^{a} / w t^{b}$, $w t^{a b}$ and $w t^{\text {blb }}$ stimulated B-cells. Each point represents one stimulation from one mouse, mean is shown ( $\geq 3$ independent experiments). Mann-Whitney test for significance. C. ELISpot specific for IgG2a (top) and IgE (bottom) were performed on in vitro stimulated B-cells from $\Delta 3^{\prime} \mathrm{RR}, \Delta 3^{\prime} \mathrm{RR}^{\mathrm{a}} / w t^{\mathrm{b}}$, $w t^{\mathrm{ab}}$ and $w t^{\mathrm{b} b}$. Data shown are from 3 independent experiments with at least 2 mice. Mean $+/$ - s.d. is shown. Mann-Whitney test for significance. 
Table 1: Rescued-SHM in $\Delta 3^{\prime} R^{a} / w t^{b}$ mice

\begin{tabular}{|c|c|c|c|c|c|}
\hline & Genotypes & \multicolumn{2}{|c|}{$\Delta 3^{\prime} R R$} & \multicolumn{2}{|c|}{$\Delta 3^{\prime} R R^{a} / w t^{b}$} \\
\hline & Alleles & $\begin{array}{c}\mathbf{l g \kappa} \\
\text { (control) }\end{array}$ & $\begin{array}{l}\text { Allele a } \\
\left(\triangle 3^{\prime} R R\right)\end{array}$ & $\begin{array}{l}\text { Allele a } \\
\left(\triangle 3^{\prime} R R\right)\end{array}$ & $\begin{array}{c}\text { Allele b } \\
(w t)\end{array}$ \\
\hline & Analyzed regions & $3 J_{k} 5$ & $3 J_{H} 4$ & $3 J_{H} 4$ & $3 J_{H} 4$ \\
\hline \multirow{3}{*}{ 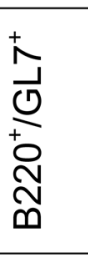 } & Total number of mutations & 515 & 663 & 2034 & 11,954 \\
\hline & $\begin{array}{l}\text { Total length analyzed } \\
\text { (base pairs) }\end{array}$ & 30,470 & 754,252 & 508,633 & $1,026,387$ \\
\hline & $\begin{array}{l}\text { Mutation frequencies } \\
\text { (per } 1000 \text { base pairs) }\end{array}$ & 16.90 & 0.89 & 3.99 & 11.65 \\
\hline \multirow{3}{*}{ 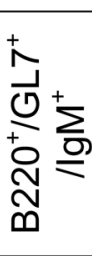 } & Total number of mutations & 143 & 8 & 24 & 135 \\
\hline & $\begin{array}{l}\text { Total length analyzed } \\
\text { (base pairs) }\end{array}$ & 24,376 & 49,632 & 44,462 & 38,775 \\
\hline & $\begin{array}{l}\text { Mutation frequencies } \\
\text { (per } 1000 \text { base pairs) }\end{array}$ & 5.87 & 0.16 & 0.54 & 3.48 \\
\hline
\end{tabular}

Mutation frequencies in $3^{\prime} \mathrm{J}_{\mathrm{H}} 4$ and $3^{\prime} \mathrm{J}_{\kappa} 5$ introns in $\mathrm{B} 220^{+} / \mathrm{GL}^{+}$and $\mathrm{B} 220^{+} / \mathrm{GL}^{+} / \mathrm{IgM}^{+}$cells from homozygous $\Delta 3^{\prime} \mathrm{RR}$ and $\Delta 3^{\prime} R R^{a} / w t^{b}$ mice. Data were obtained from at least 2 experiments, $\geq 2$ mice per group, with clonally related sequences counted only once.

the accessible $\mathrm{S} \mu$ from the 3'RR-less allele to downstream $\mathrm{S}$ regions from the $w t$ allele [24]. The $I g H^{a}$ locus (from SV129 strain) drives expression of $\operatorname{IgM}^{\mathrm{a}}, \operatorname{IgG}^{\mathrm{a}}, \operatorname{IgG} 2 \mathrm{a}$, $\operatorname{IgE}^{\mathrm{a}}$ and $\operatorname{Ig} \mathrm{A}^{\mathrm{a}}$ (for which some allotype-specific antisera are available) instead of $\operatorname{IgM}^{\mathrm{b}}, \operatorname{IgG} 1^{\mathrm{b}}, \operatorname{IgG} 2 \mathrm{c}, \operatorname{IgE}^{\mathrm{b}}$ and $\operatorname{Ig} \mathrm{A}^{\mathrm{b}}$ for the $\operatorname{Ig} H^{\mathrm{b}}$ locus (from $\mathrm{C} 57 \mathrm{BL} / 6$ strain). Whether using cis- or trans-CSR, heterozygous $\Delta 3^{\prime} \mathrm{RR}^{\mathrm{a}} / w^{\mathrm{b}}$ mice should thus overwhelmingly secrete switched Ig from the accessible $I g H^{\mathrm{b}}$ constant genes, with the exception of IgG1 which is less affected by the 3'RR deletion in $\Delta 3^{\prime} R R^{\mathrm{a}} / \Delta 3^{\prime} R^{\mathrm{a}}{ }^{\mathrm{a}}$ homozygous mice [17]. We analyzed whether in heterozygous settings, the $3^{\prime}$ RR-proficient $I g H^{\mathrm{b}}$ allele can rescue some usage of the $3^{\prime} \mathrm{RR}$-dependent $\mathrm{C}$ genes (that are not accessible) from the $3{ }^{\prime} \mathrm{RR}$-deleted $\lg \mathrm{H}^{\text {a }}$ allele.

In sera, we observed that instead of following gene dosage, allotype-specific $\operatorname{IgA}^{\mathrm{a}}$ and $\operatorname{IgG2a}$ levels (measuring $C \gamma^{a}$ and $C \gamma 2 a$ CSR on the $\Delta 3^{\prime} R R^{a}$ allele) significantly increased in heterozygous compared to homozygous $\Delta 3^{\prime} R R^{a}$ mice (Figure $3 \mathrm{~A}$ ). The same was true for in vitro stimulated B-cells both by evaluating secretion of the $\operatorname{IgE}^{\mathrm{a}}$ and $\mathrm{IgG} 2 \mathrm{a}$ allotypes in supernatants (Figure 3B) and by directly counting $\operatorname{IgE}^{\mathrm{a}}$ and $\operatorname{IgG} 2 \mathrm{a}$ switched plasma cells by ELISpot (Figure 3C). Rescued CSRaccessibility of $3^{\prime} \mathrm{RR}$-deleted $\operatorname{Ig} H^{\mathrm{a}} \mathrm{C}$ genes thus indicates inter-allelic 3'RR trans-activation.

\section{Trans-activation by the $w t^{\mathrm{b}}$ allele functional 3'RR during SHM}

Potential trans-complementation of a SHM defect in Peyer's patches GC B-cells was checked downstream of rearranged $\mathrm{J}_{\mathrm{H}} 4$ segments (through either cloning/highfidelity sequencing or high throughput next generation sequencing (NGS)). As previously documented [16], $\operatorname{IgH}$ SHM was deficient upon $\Delta 3^{\prime}$ RR homozygosity $(0.89 \%$ o bp in $\operatorname{IgH} v s 16.9 \%$ for $I g \kappa$ ) (Table 1, Figures $4 \mathrm{~A}$ and 4B). In $\Delta 3^{\prime} R^{\mathrm{a}} / w t^{\mathrm{b}}$ mice, SHM on the $w t^{\mathrm{b}}$ allele reached $11.565 \%$ bp (Table 1, Figures 4A and 4B). Interestingly, the $\Delta 3^{\prime} R^{\mathrm{a}}$ allele from heterozygous cells reached an intermediate $3.99 \%$ level, which although below the $w t^{b}$ level $(p<0.0001)$ is 4 -fold higher than with a biallelic 3 'RR defect $(p<0.0001)$ (Table 1, Figures 4A and 4B). Even though the higher error background level with NGS was less adapted for evaluating low-level SHM on the $\triangle 3$ 'RR allele, it confirmed cloning/sequencing data from a previous study [13] and additionally indicated on a high number of reads that SHM hotspots were superimposed in $w t^{\mathrm{b}}$ and $\Delta 3^{\prime} R R^{\mathrm{a}}$ alleles in a heterozygous context providing trans-complementation (Figure 4C), Transcomplementation by $3^{\prime} \mathrm{RR}^{\mathrm{b}}$ rescues SHM with a typical AID pattern (increasing around RGYW/WRCY sequence targets) although this occurs at a lower level than in cis

Some unsorted VDJa sequences might have been joined with $3^{\prime} \mathrm{RR}^{\mathrm{b}}$ through trans-CSR, then conventionally promoting SHM in cis. To exclude that, we also studied sorted unswitched $\mathrm{IgM}^{+} / \mathrm{B} 220^{+} / \mathrm{GL}^{+}$cells: as expected SHM was lower but confirmed the above-described variations in 3'RR-less loci compared with either heterozygosity to homozygosity. $\Delta 3$ 'RR homozygous cells showed strongly decreased SHM $(0.16 \%$ for $\operatorname{IgH}$ vs $5.87 \%$ for $I g \kappa$ ) (Table 1, Figure 4D). By contrast, in $\Delta 3^{\prime} R^{a} / w t^{b}$ cells, SHM on the $\Delta 3^{\prime} R^{a}{ }^{a}$ allele increased by 3 -fold $(0.54 \%)(p<0.01)$ (Table 1, Figure 4D), although lower than the $3.48 \%$ yielded in parallel on $w t^{\mathrm{b}}$ alleles 
(Table 1, Figure 4D). Accordingly, the 3'RR-deficient allele showed less unmutated sequences when under heterozygosity, but more with 1-3 mutations, while no highly mutated sequence appeared in such $\operatorname{IgM}^{+}$cells (Figure 4D).

Altogether, the $3^{\prime} \mathrm{RR}$ promotes inter-allelic interactions in both transgenic and endogenous $\mathrm{Ig} H$ loci. In addition to its role in promoting interactions between $\operatorname{IgH}$ alleles, the 3'RR also supports AID recruitment on $\mathrm{S}$ (for CSR) and $\mathrm{VH}$ regions (for SHM), not only in cis but also in trans. We observed allele pairing in in vitro stimulated B-cells and measured CSR and SHM in trans showing 3'RR-dependent transvection in at least a fraction of activated B-cells. Even if 3'RR-dependent AID-initiated lesions occur less frequently in trans than in cis, they break the paradigm that the $3^{\prime} \mathrm{RR}$ is simply a cis-regulatory element and demonstrate a missing step that is important for generating the frequent interallelic CSR junctions (found in roughly $20 \%$ of B-cells). Functional transvection occurs during the window of time of AID activity and prior to any DNA recombination. Gene trans-activation occurs in yeast, drosophila and mammals and cis-regulatory elements can interact at long-distance [30]. IgH locus physiology is known to involve different types of intrachromosomal loops that contribute to recombination [19, $31,32]$. In addition, we now demonstrate that the B-cell nucleus also supports $\operatorname{IgH}$ inter-allelic contacts allowing first transvection and eventually trans-CSR. It remains to be determined whether trans-interactions reflect bystander proximity after binding identical transcriptional factors, enzymes that may be rate-limiting and only concentrate in a few locations of the nucleus, or whether inter-allelic proximity is functionally important for optimal B cell maturation, by promoting use of the alternate trans-CSR pathway.

Non-coding RNAs might contribute to trans interactions as they were shown to modulate bridges and potential DNA loops in cis between distant $\operatorname{IgH}$ transcriptional regulatory elements, promoting AID accessibility [4].

Deleterious off-target interactions (which can promote translocations) affect $I g$ loci, and $c$-myc often co-localizes with the $\operatorname{IgH}$ transcription factory [33, 34]. AID is normally recruited at S regions by 3 'RRdependent chromatin marks [29] but $c$-myc proximity combined with a high frequency of off-target breaks can result in oncogenic translocations $[35,36]$. An attractive hypothesis is that transvection between fragile $I g H$ loci has evolved beside the major cis-CSR pathway in order to further promote legitimate and safe interactions between homologous alleles. Interestingly, this could then also help out-compete hazardous interactions with illegitimate partners. The 3'RR super-enhancer might thus favor transcription and remodeling of $\mathrm{IgH}$ loci (together with dangerous partners), and be an intrinsic caretaker of the B-cell genome.

\section{EXPERIMENTAL PROCEDURES}

\section{Mice}

Our research has been approved by the local ethics committee review board. Transgenic 995, 820 and 3' enhancer deleted $820(\Delta 820)$ mice were a kind gift of Dr. Wesley Dunnick (Figure 1B). 3'RR-mediated inter-allelic trans-interactions were studied using a 3 'RR-deleted $\left(\Delta 3^{\prime} \mathrm{RR}\right)$ locus (with altered CSR and SHM $\left.[16,17]\right)$ either under homozygosity or with heterozygous $\Delta 3^{\prime} R^{a}$ / wild-type $(w t)^{\mathrm{b}}$ alleles of different $\operatorname{Ig} H^{\mathrm{ab}}$ allotypes (Figure 2A). 3'RR-deficient ( $\Delta 3^{\prime}$ RR) Ig $H^{\text {a/a }}$ mice were bred with wt $I g H^{\mathrm{b} / \mathrm{b}}(\mathrm{C} 57 \mathrm{BL} / 6)$ mice or enhancer E $\mu$-deficient mice $(\triangle \mathrm{E} \mu)$ mice [37] (Figure 2F). 8-10 weeks old littermates were used in all experiments. Allotypes known for several $\operatorname{Ig} H^{\mathrm{a}}$ and $\operatorname{Ig} \mathrm{H}^{\mathrm{b}}$ constant genes can monitor the relative expression of both loci in heterozygous $\operatorname{Ig} H^{\mathrm{a} b}$ mice.

\section{Heavy chain transgene chromosomal insertion site in lines 995 and 820}

Genomic DNA from transgenic lines 995 and 820 was digested with MboI, diluted, and ligated to form circles, some of which include the $3^{\prime}$ end of the transgene and the adjacent chromosomal sequences from the host mouse (either C57BL/6 or SJL). PCR primers were selected for an orientation that would amplify a small portion of the 3' end of the transgene and the adjacent chromosomal sequences in between. For line 820, the chromosomal sequences matched C57BL/6 chromosome 7 sequences (491 of 497 bases) at position $122 \mathrm{Mb}$ (of 145 $\mathrm{Mb}$ total length).

\section{Cell culture}

Splenocytes were collected, red blood cells were lysed and CD43 depleted using CD43 microbeads (Miltenyi Biotec). B splenocytes were cultured 1, 2, 3, 4 or 5 days (for 3D-FISH) or 4 days (for ELISA and ELISpot) in RPMI containing $10 \%$ FCS with LPS $(20 \mu \mathrm{g} / \mathrm{mL})$ or with anti-CD40 $(5 \mu \mathrm{g} / \mathrm{ml})(\mathrm{RD}$ systems $)+\mathrm{IL} 4(40 \mathrm{ng} / \mathrm{mL})$ (Peprotech) or LPS $(20 \mu \mathrm{g} / \mathrm{mL})+$ IFN $\gamma(2 \mathrm{ng} / \mathrm{mL})(\mathrm{RD}$ systems).

\section{D-FISH}

Interphase DNA FISH was performed as previously described [10] with minor adaptation. In vitro activated B-cells were dropped onto poly-L-lysine slides and fixed with $4 \%$ paraformaldehyde for $10 \mathrm{~min}$ at room temperature (RT). After washing with PBS, cells were permeabilized with pepsin $0.02 \% / \mathrm{HCl} 0.1 \mathrm{M}$ for $15 \mathrm{~min}$ at $\mathrm{RT}$, then 


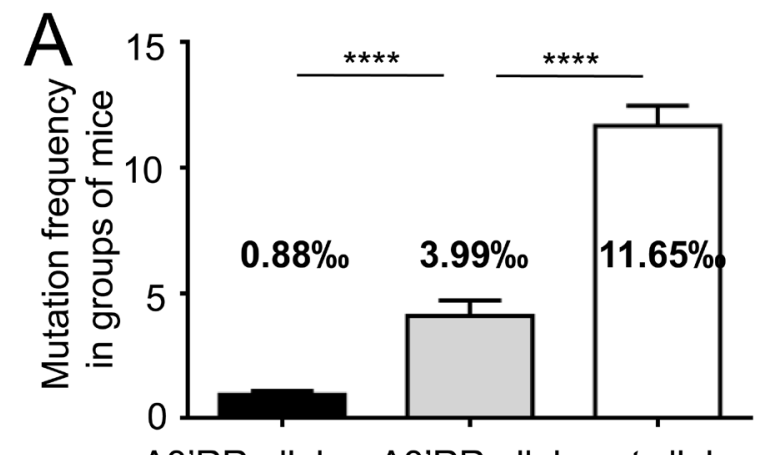

$\triangle 3^{\prime}$ RR alleles $\triangle 3^{\prime}$ RR allele $w t$ allele

Homozygous Heterozygous

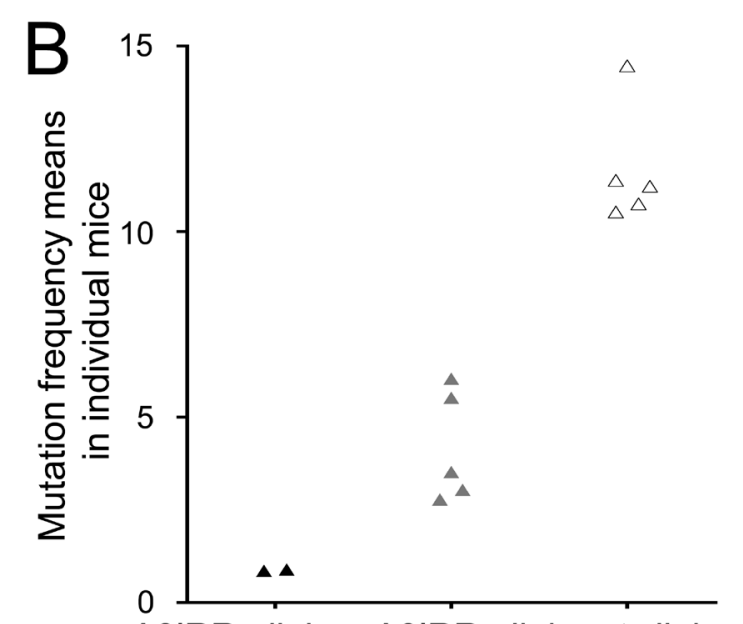

$\Delta 3^{\prime} R R$ alleles $\Delta 3^{\prime} R R$ allele $w t$ allele

Homozygous Heterozygous

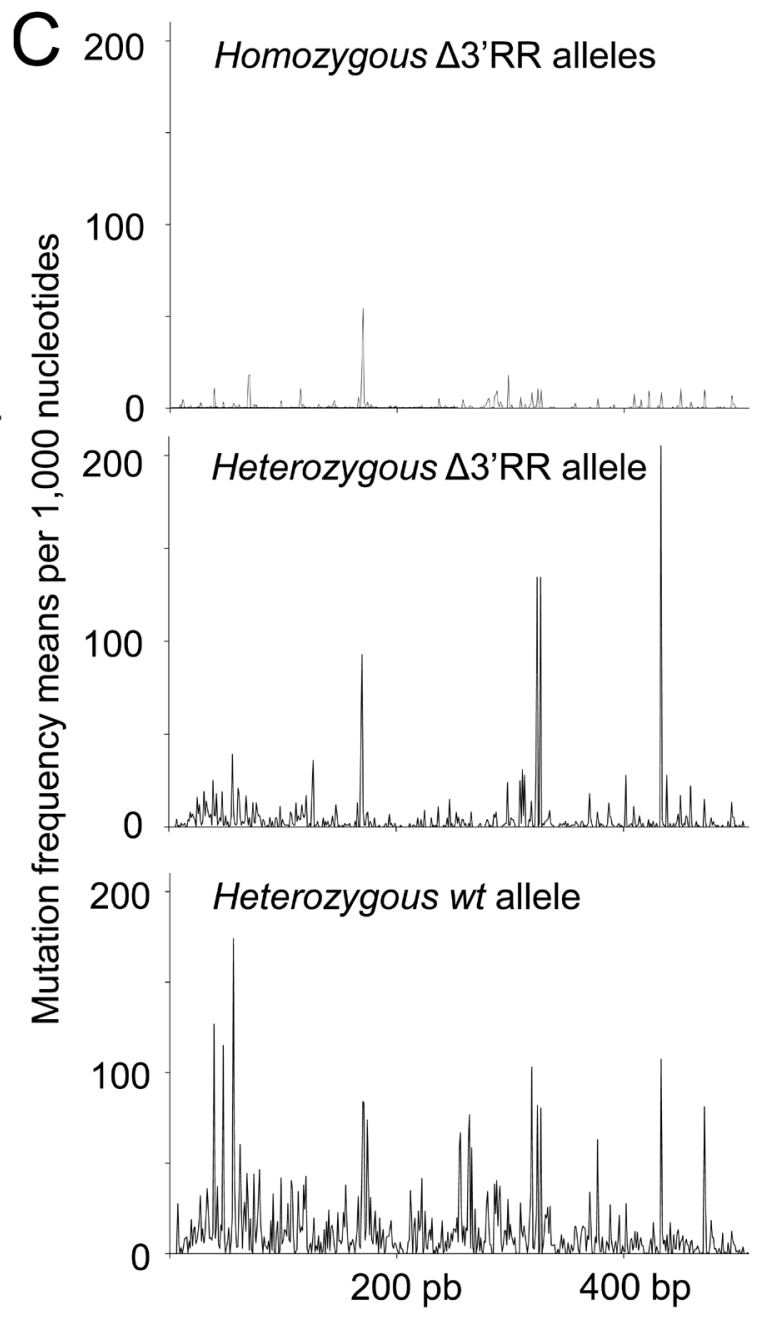

7 to $9 \geq 10$

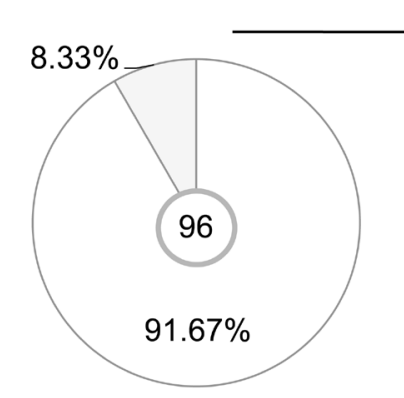

$\triangle 3^{\prime} R R$ (SHM 0.16\%o)

Homozygous

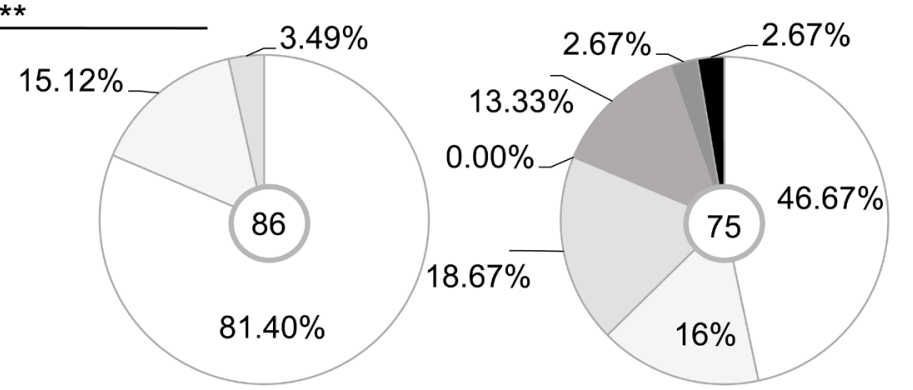

$\Delta 3$ 'RR allele (SHM 0.54\%o) $\quad$ wt allele (SHM 3.48\%o)

Heterozygous

Figure 4: The 3'RR partially rescues $\mathbf{S H M}$ in trans on a 3'RR-cis-deficient $\operatorname{IgH}$ allele. A. Mutation frequency in 3'J 4 intron from Peyer's patches $\left(\mathrm{B} 220^{+} / \mathrm{GL}^{+}\right)$in $\Delta 3^{\prime} \mathrm{RR} / \Delta 3^{\prime} \mathrm{RR}$ mice and in $\Delta 3^{\prime} \mathrm{RR}^{\mathrm{a}}$ and $w t^{\mathrm{b}}$ alleles from $\Delta 3^{\prime} \mathrm{RR}^{\mathrm{a}} / w t^{\mathrm{b}}$ mice. Mean $+/-$ s.d. is shown. Mann-Whitney test for significance. B. Mutation frequency as in (A), but with each point representing an individual mouse in order to evaluate the dispersion of the results when SHM is measured in groups of mice with homogeneous genotype. C. Graph of mutation frequencies along the sequenced $\mathrm{J}_{\mathrm{H}} 4$ flanking region in homozygous $\Delta 3^{\prime} R R$ mice (top) and in $\Delta 3^{\prime} R^{\mathrm{a}}$ (middle) and $w t^{\mathrm{b}}$ (bottom) alleles from $\Delta 3^{\prime} \mathrm{RR}^{\mathrm{a}} / w t^{\mathrm{b}}$ mice. D. Mutation frequencies in $3^{\prime} \mathrm{J}_{\mathrm{H}} 4$ intron in Peyer's patches $\mathrm{B} 220^{+} / \mathrm{GL}^{+} / \mathrm{IgM}^{+}$cells from homozygous $\Delta 3^{\prime} \mathrm{RR}$ and $\Delta 3^{\prime} R^{a} / w t^{b}$ heterozygous mice. Data were obtained from at least 3 mice per group and clonally related sequences were counted only once. Khi2 test for significance. 
washed and post-fixed with $1 \%$ paraformaldehyde for 5 min at RT, denatured for $5 \mathrm{~min}$ in $70 \%$ formamide, $2 \mathrm{X}$ SSC at $72^{\circ} \mathrm{C}$ and hybridized overnight at $37^{\circ} \mathrm{C}$. The $\operatorname{IgH}$ (RP23-109B20) probe (encompassing an AID-targeted region from the DH cluster to $\mathrm{C} \gamma 2 \mathrm{a}$ ) and $\mathrm{RP} 23-436 \mathrm{M} 24$ was respectively labelled with dCTP-biotin (Invitrogen) or with dUTP-digoxigenin (Roche). Slides were washed in $1 \mathrm{X} \mathrm{SSC}$ at $72^{\circ} \mathrm{C}$ for $5 \mathrm{~min}$, incubated with steptavidinAlexa Fluor 594 (1/200, BD biosciences) or with antidigoxigenin-Alexa Fluor 488 (Abcam) 1h at RT, and mounted with vectashield containing DAPI (Vector labs). Images were acquired with an epifluorescence microscope (LEICA DMI6000B) or by confocal microscopy on a Leica SP5 AOBS system (Acousto-Optical Beam Splitter). Optical sections separated by 0.2 to $0.3 \mu \mathrm{m}$ were collected and stacks were de-convoluted and analyzed using Huygens and Volocity softwares, respectively. Separation of alleles was measured in 3D from the centre of mass of each signal. Volumetric pixel size was $0.064 \mu \mathrm{m}$ in $\mathrm{xy}$ and $0.2 \mu \mathrm{m}$ in $\mathrm{z}$-direction.

\section{Chromosome conformation capture (3C)}

$10^{7}$ cells were fixed with PBS $10 \% \mathrm{FCS}$ and $1 \%$ formaldehyde for $10 \mathrm{~min}$ at RT, stopped with glycine $(0.125 \mathrm{M})$. Cells were lysed in Tris $10 \mathrm{mM}, \mathrm{NaCl} 10 \mathrm{mM}$, NP40 2\%, supplemented with protease inhibitors, with 10 strokes of a dounce homogeneizer (Pestle A). Nuclei were resuspended in restriction buffer, permeabilized with $\operatorname{SDS}(0.1 \%)$ for $10 \mathrm{~min}$ at $37^{\circ} \mathrm{C}$ and triton $\mathrm{X}-100$ (1\%) was added. DNA was restricted with HindIII (900U) overnight at $37^{\circ} \mathrm{C}$. After HindIII inactivation DNA was ligated with T4 DNA ligase (NEB) overnight at $16^{\circ} \mathrm{C}$ in $8 \mathrm{~mL}$. The crosslink was reversed by proteinase $\mathrm{K}(500 \mu \mathrm{g})$ overnight at $65^{\circ} \mathrm{C}$ and then $300 \mu \mathrm{g}$ of RNAse A was added and incubated $1 \mathrm{~h}$ at $37^{\circ} \mathrm{C}$. DNA was phenol/chloroform extracted and quantified with Qubit (Invitrogen).

The linear range of PCR amplification was determined by serial dilution of the control and the crosslinked chromatin templates. PCR was performed with Herculase Taq polymerase (Agilent) on 200ng DNA using E $\mu$ primer: TTGACATTCTGGTCAAAACGGC and hs4: CAACCTGTGTCCCTAGAGGAGT or calreticulin primers $\mathrm{F}$ : CCCAAACCACCACTACCATTACA and R : GATGAACTGCCCTATCCTGAGTC $\left(95^{\circ} \mathrm{C} 2 \mathrm{~min}\right.$, 45 cycles $95^{\circ} \mathrm{C} 20 \mathrm{sec}, 56^{\circ} \mathrm{C} 20 \mathrm{sec}, 72^{\circ} \mathrm{C} 15 \mathrm{sec}$ and $72^{\circ} \mathrm{C} 3 \mathrm{~min}$ ). PCR products were quantified with Image J. Relative crosslinking frequencies were calculated as described [19]. BAC RP23-109B20, 199M11 and RP23$421 \mathrm{H} 21$ provided control templates.

\section{Allotype-specific ELISA}

ELISA for the presence of "a" allotype $\operatorname{IgA}$, $\operatorname{IgG} 2 \mathrm{a}$, and $\operatorname{IgE} \mathrm{E}^{\mathrm{a}}$ were performed on sera or supernatant from $\Delta 3^{\prime}$ RR homozygous, $\Delta 3^{\prime} \mathrm{RR}^{\mathrm{a}} / w t^{\mathrm{b}}$ heterozygous, $w t^{\mathrm{a} / \mathrm{b}}$ and $w t^{\mathrm{b} / \mathrm{b}}$ mice or in vitro stimulated B-cells. A pool of $w t^{\mathrm{a} / \mathrm{b}}$ sera was used as standard. Plates were coated with monoclonal antibodies specific for $\operatorname{IgA}^{\mathrm{a}}$ (clone EC2, BD Pharmingen) or IgG2a (731926, Beckman coulter) overnight, samples were then incubated $2 \mathrm{~h}$ at $37^{\circ} \mathrm{C}$. After washing AP-conjugates goat anti mouse IgA (1040-04, Southern biotech) or IgG2a (1080-04, Southern biotech) were incubated $1 \mathrm{~h}$ at $37^{\circ} \mathrm{C}$. After washing and addition of AP substrate (Sigma), optic density was measured at $400 \mathrm{~nm}$. For ELISA IgEa, black 96-well Immuno plates (Thermoscientific) were coated overnight with anti-IgE (732385, Beckman coulter). Samples were incubated 5h at $37^{\circ} \mathrm{C}$ and, after washing, with biotinylated anti-mouse $\mathrm{IgE}^{\mathrm{a}}$ (BLE408804, Ozyme) overnight at $37^{\circ} \mathrm{C}$. After washing, streptavidin-AP (Sigma) was incubated $45 \mathrm{~min}$ at $37^{\circ} \mathrm{C}$. After washing, AP activity was assayed using 4-methylumbelliferyl phosphate (Molecular probes) and fluorescence was read at $449 \mathrm{~nm}$.

\section{ELISpot}

For evaluation of $\operatorname{IgG} 2 \mathrm{a}$ or $\operatorname{IgE}^{\mathrm{a}}$ secretion, cells were seeded in duplicate at a density starting at $5 \times 10^{4} /$ well, followed by 5 -fold serial dilutions in culture medium on a 96-well MultiScreen HTS plate (Millipore) coated with $1.5 \mu \mathrm{g}$ per well of anti-IgG2a or anti-IgE ${ }^{\mathrm{a}}$. Cells were incubated $7 \mathrm{~h}$ at $37^{\circ} \mathrm{C}$ and then removed by washing with PBS/Tween $0.01 \%$. Plates were then incubated $1 \mathrm{~h}$ at 37 ${ }^{\circ} \mathrm{C}$ with $1 \mu \mathrm{g} /$ well of alkaline phosphatase-coupled antiIgG2a or biotinylated-anti-IgE ${ }^{\mathrm{a}}$. After washing with PBS/ Tween $0.01 \%$, streptavidin-AP (Sigma) was incubated 45 $\min$ at $37^{\circ} \mathrm{C}$ (for $\operatorname{IgE}^{\mathrm{a}}$ ). After washing, addition of $100 \mu \mathrm{L}$ of BCIP/NBT alkaline phosphatase substrate (Millipore), new washing and drying, images were taken with NI-E microscope (Nikon) and analyzed for spots numbers with the Nis-Ar software (Nikon).

\section{Flow cytometry and cell sorting}

Cell suspensions from Peyer's patches were labeled with anti-B220-APC- (Clone RA3-6B2, Biolegend), GL7-PE- (BD), anti-IgM-FITC (Clone eB121-15F9, ebiosciences) -conjugated antibodies. Sorting of $\mathrm{B} 220^{+} /$ $\mathrm{GL}^{+}$or $\mathrm{B} 220^{+} / \mathrm{GL}^{+} / \mathrm{IgM}^{+}$B-cells was performed on a FACS ARIA 3 (BD Biosciences). Cell sorting quality was validated when SHM frequency at the Igк locus was superior to $5 \%$.

\section{Somatic hypermutation analysis}

SHM analysis was performed as described [16] from sorted $\mathrm{B} 220^{+} / \mathrm{GL}^{+}$or $\mathrm{B} 220^{+} / \mathrm{GL}^{+} /$ $\mathrm{IgM}^{+}$B-cells cells. For NGS experiment, PCR 
was performed using primers containing GS junior adaptors and sequences specific of $\mathrm{V}$ region (GCGAAGCTTARGCCTGGGRCTTCAGTGAAG) and $\mathrm{J}_{\mathrm{H}} 4$ intron (AGGCTCTGAGATCCCTAGACAG). Amplifications were performed with Phusion ${ }^{\circledR}$ HighFidelity DNA Polymerase (New England Biolabs) according to the following program: DNA was denatured $30 \mathrm{~s}$ at $98^{\circ} \mathrm{C}$ and then submitted to 42 cycles consisting of $98^{\circ} \mathrm{C}$ for $10 \mathrm{~s}, 60^{\circ} \mathrm{C}$ for $30 \mathrm{~s}$ and $72^{\circ} \mathrm{C}$ for $30 \mathrm{~s}$, and 1 cycle at $72^{\circ} \mathrm{C}$ for $10 \mathrm{~min}$.

PCR products were first purified using NucleoSpin kit (Macherey-Nagel) and then using Ampure beads (Beckman Coulter). First a PCR emulsion (GS Junior+ emPCR Kit (Lib-A), Roche) was performed and finally PCR products were sequenced using the GS junior sequencing kit XL+ (Roche).

\section{Statistical analysis}

Statistical tests were performed using GraphPad Prism $\left({ }^{*} p<0.05,{ }^{* *} p<0.01,{ }^{* * *} p<0.001,{ }^{* * * *} p<\right.$ 0.0001).

\section{Abbreviations}

IgH, Immunoglobulin heavy chain; CSR, classswitch recombination ; 3'RR, 3' regulatory region; AID, activation-induced cytidine deaminase ; SHM, somatic hypermutation

\section{ACKNOWLEDGMENTS}

We thank Dr. Wesley Dunnick for providing IgH transgenic mice, and Dr. Max Cooper, Olivier Bernard, Michèle Goodhardt and Jeanne Cook-Moreau for critical reading of the manuscript. SLN and BL were supported by Association pour la Recherche sur le Cancer (ARC). We are grateful to M. Brousse, M. Faïsse, S. Desforges and B. Remerand for technical help, and to the Limoges University facilities for FACS sorting (C. Ouk) and sequencing (R. Moulinas). This work was supported by grants from ARC (PGA120150202338), Agence Nationale de la Recherche (ANR grant 16-CE15-0019-01), Institut National du Cancer (INCa grant \#9363), Ligue Nationale contre le Cancer and Région Aquitaine-Limousin-PoitouCharente.

\section{CONFLICTS OF INTEREST}

The authors declare that they have no conflict of interest.

\section{Authorship contributions}

SLN, BL, CC, WD, SL and AG performed the experiments. EP and YD contributed essential reagents and mice. MC designed and supervised the study. SLN, BL, JS and $\mathrm{MC}$ analyzed the data and wrote the manuscript.

\section{Editorial note}

This paper has been accepted based in part on peerreview conducted by another journal and the authors' response and revisions as well as expedited peer-review in Oncotarget.

\section{REFERENCES}

1. Chen J-L, Huisinga KL, Viering MM, Ou SA, Wu C -tin., Geyer PK. Enhancer action in trans is permitted throughout the Drosophila genome. Proc Natl Acad Sci USA. 2002; 99 : 3723-8. doi: 10.1073/pnas.062447999.

2. Dowen JM, Fan ZP, Hnisz D, Ren G, Abraham BJ, Zhang LN, Weintraub AS, Schuijers J, Lee TI, Zhao K, Young RA. Control of cell identity genes occurs in insulated neighborhoods in mammalian chromosomes. Cell. 2014; 159: 374-87. doi: 10.1016/j.cell.2014.09.030.

3. Park S-K, Xiang Y, Feng X, Garrard WT. Pronounced cohabitation of active immunoglobulin genes from three different chromosomes in transcription factories during maximal antibody synthesis. Genes Dev. 2014; 28: 115964. doi: 10.1101/gad.237479.114.

4. Pefanis E, Wang J, Rothschild G, Lim J, Kazadi D, Sun J, Federation A, Chao J, Elliott O, Liu Z-P, Economides AN, Bradner JE, Rabadan R, et al. RNA exosome-regulated long non-coding RNA transcription controls superenhancer activity. Cell. 2015; 161: 774-89. doi: 10.1016/j. cell.2015.04.034.

5. Lewis EB. The theory and application of a new method of detecting chromosomal rearrangements in Drosophila melanogaster. American Naturalist. 1954; 88: 225-39.

6. Liu H, Huang J, Wang J, Jiang S, Bailey AS, Goldman DC, Welcker M, Bedell V, Slovak ML, Clurman B, Thayer M, Fleming WH, Epner E. Transvection mediated by the translocated cyclin D1 locus in mantle cell lymphoma. J Exp Med. 2008; 205: 1843-58. doi: 10.1084/jem.20072102.

7. Herman H, Lu M, Anggraini M, Sikora A, Chang Y, Yoon BJ, Soloway PD. Trans allele methylation and paramutation-like effects in mice. Nat Genet. 2003; 34: 199-202. doi: 10.1038/ng1162.

8. Hewitt SL, Farmer D, Marszalek K, Cadera E, Liang H-E, $\mathrm{Xu}$ Y, Schlissel MS, Skok JA. Association between the Igk and Igh immunoglobulin loci mediated by the 3' Igk enhancer induces "decontraction" of the Igh locus in pre-B cells. Nat Immunol. 2008; 9: 396-404. doi: 10.1038/ni1567. 
9. Holwerda SJB, van de Werken HJG, Ribeiro de Almeida C, Bergen IM, de Bruijn MJW, Verstegen MJAM, Simonis M, Splinter E, Wijchers PJ, Hendriks RW, de Laat W. Allelic exclusion of the immunoglobulin heavy chain locus is independent of its nuclear localization in mature B cells. Nucleic Acids Res. 2013; 41: 6905-16. doi: 10.1093/nar/ gkt491.

10. Hewitt SL, Yin B, Ji Y, Chaumeil J, Marszalek K, Tenthorey J, Salvagiotto G, Steinel N, Ramsey LB, Ghysdael J, Farrar MA, Sleckman BP, Schatz DG, et al. RAG-1 and ATM coordinate monoallelic recombination and nuclear positioning of immunoglobulin loci. Nat Immunol. 2009; 10: 655-64. doi: 10.1038/ni.1735.

11. Delpy L, Sirac C, Le Morvan C, Cogné M. Transcriptiondependent somatic hypermutation occurs at similar levels on functional and nonfunctional rearranged $\operatorname{IgH}$ alleles. J Immunol. 2004; 173: 1842-8.

12. Yeap L-S, Hwang JK, Du Z, Meyers RM, Meng F-L, Jakubauskaitė A, Liu M, Mani V, Neuberg D, Kepler TB, Wang JH, Alt FW. Sequence-Intrinsic Mechanisms that Target AID Mutational Outcomes on Antibody Genes. Cell. 2015; 163: 1124-37. doi: 10.1016/j.cell.2015.10.042.

13. Peron S, Laffleur B, Denis-Lagache N, Cook-Moreau J, Tinguely A, Delpy L, Denizot Y, Pinaud E, Cogne M. AID-Driven Deletion Causes Immunoglobulin Heavy Chain Locus Suicide Recombination in B Cells. Science. 2012; 336: 931-4. doi: 10.1126/science.1218692.

14. Dunnick WA, Shi J, Fontaine C, Collins JT. Transgenes of the mouse immunoglobulin heavy chain locus, lacking distal elements in the 3' regulatory region, are impaired for class switch recombination. PLoS ONE. 2013; 8: e55842. doi: 10.1371/journal.pone.0055842.

15. Pinaud E, Marquet M, Fiancette R, Péron S, Vincent-Fabert C, Denizot Y, Cogné M. The IgH locus 3' regulatory region: pulling the strings from behind. Adv Immunol. 2011; 110: 27-70. doi: 10.1016/B978-0-12-387663-8.00002-8.

16. Rouaud P, Vincent-Fabert C, Saintamand A, Fiancette R, Marquet M, Robert I, Reina-San-Martin B, Pinaud E, Cogné M, Denizot Y. The IgH 3' regulatory region controls somatic hypermutation in germinal center B cells. J Exp Med. 2013; 210: 1501-7. doi: 10.1084/jem.20130072.

17. Vincent-Fabert C, Fiancette R, Pinaud E, Truffinet V, Cogné N, Cogné M, Denizot Y. Genomic deletion of the whole $\operatorname{IgH} 3$ ' regulatory region (hs3a, hs 1, 2, hs 3b, and hs4) dramatically affects class switch recombination and Ig secretion to all isotypes. Blood. 2010; 116: 1895-8. doi: 10.1182/blood-2010-01-264689.

18. Meng F-L, Du Z, Federation A, Hu J, Wang Q, KiefferKwon K-R, Meyers RM, Amor C, Wasserman CR, Neuberg D, Casellas R, Nussenzweig MC, Bradner JE, et al. Convergent transcription at intragenic super-enhancers targets AID-initiated genomic instability. Cell. 2014; 159: 1538-48. doi: 10.1016/j.cell.2014.11.014.

19. Wuerffel R, Wang L, Grigera F, Manis J, Selsing E, Perlot T, Alt FW, Cogne M, Pinaud E, Kenter AL. S-S synapsis during class switch recombination is promoted by distantly located transcriptional elements and activation-induced deaminase. Immunity. 2007; 27: 711-22. doi: 10.1016/j. immuni.2007.09.007.

20. Truffinet V, Pinaud E, Cogné N, Petit B, Guglielmi L, Cogné M, Denizot Y. The 3' IgH locus control region is sufficient to deregulate a c-myc transgene and promote mature B cell malignancies with a predominant Burkitt-like phenotype. J Immunol. 2007; 179: 6033-42.

21. Aupetit C, Drouet M, Pinaud E, Denizot Y, Aldigier JC, Bridoux F, Cogné M. Alleles of the alpha1 immunoglobulin gene 3' enhancer control evolution of IgA nephropathy toward renal failure. Kidney Int. 2000; 58: 966-71. doi: 10.1046/j.1523-1755.2000.00253.x.

22. Gostissa M, Yan CT, Bianco JM, Cogné M, Pinaud E, Alt FW. Long-range oncogenic activation of Igh-c-myc translocations by the Igh 3' regulatory region. Nature. 2009; 462: 803-7. doi: 10.1038/nature08633.

23. Chapuy B, McKeown MR, Lin CY, Monti S, Roemer MGM, Qi J, Rahl PB, Sun HH, Yeda KT, Doench JG, Reichert E, Kung AL, Rodig SJ, et al. Discovery and characterization of super-enhancer-associated dependencies in diffuse large B cell lymphoma. Cancer Cell. 2013; 24: 777-90. doi: 10.1016/j.ccr.2013.11.003.

24. Dougier H-L, Reynaud S, Pinaud E, Carrion C, Delpy L, Cogné M. Interallelic class switch recombination can reverse allelic exclusion and allow trans-complementation of an IgH locus switching defect. Eur J Immunol. 2006; 36 : 2181-91. doi: 10.1002/eji.200535529.

25. Kingzette M, Spieker-Polet H, Yam PC, Zhai SK, Knight KL. Trans-chromosomal recombination within the Ig heavy chain switch region in B lymphocytes. Proc Natl Acad Sci USA. 1998; 95: 11840-5.

26. Laffleur B, Bardet SM, Garot A, Brousse M, Baylet A, Cogné M. Immunoglobulin genes undergo legitimate repair in human B cells not only after cis- but also frequent transclass switch recombination. Genes Immun. 2014; 15: 341-6. doi: 10.1038/gene.2014.25.

27. Reynaud S, Delpy L, Fleury L, Dougier H-L, Sirac C, Cogné M. Interallelic class switch recombination contributes significantly to class switching in mouse B cells. J Immunol. 2005; 174: 6176-83.

28. Dunnick WA, Collins JT, Shi J, Westfield G, Fontaine C, Hakimpour P, Papavasiliou FN. Switch recombination and somatic hypermutation are controlled by the heavy chain 3' enhancer region. J Exp Med. 2009; 206: 2613-23. doi: 10.1084/jem.20091280.

29. Saintamand A, Rouaud P, Saad F, Rios G, Cogné M, Denizot Y. Elucidation of $\operatorname{IgH} 3$ ' region regulatory role during class switch recombination via germline deletion. Nat Commun. 2015; 6: 7084. doi: 10.1038/ncomms8084.

30. Kieffer-Kwon K-R, Tang Z, Mathe E, Qian J, Sung M-H, Li G, Resch W, Baek S, Pruett N, Grøntved L, Vian L, Nelson S, Zare H, et al. Interactome maps of mouse gene 
regulatory domains reveal basic principles of transcriptional regulation. Cell. 2013; 155: 1507-20. doi: 10.1016/j. cell.2013.11.039.

31. Proudhon C, Hao B, Raviram R, Chaumeil J, Skok JA. Long-Range Regulation of V(D)J Recombination. Adv Immunol. 2015; 128: 123-82. doi: 10.1016/ bs.ai.2015.07.003.

32. Rocha PP, Raviram R, Fu Y, Kim J, Luo VM, Aljoufi A, Swanzey E, Pasquarella A, Balestrini A, Miraldi ER, Bonneau R, Petrini J, Schotta G, et al. A DamageIndependent Role for 53BP1 that Impacts Break Order and Igh Architecture during Class Switch Recombination. Cell Rep. 2016; doi: 10.1016/j.celrep.2016.05.073.

33. Osborne CS, Chakalova L, Brown KE, Carter D, Horton A, Debrand E, Goyenechea B, Mitchell JA, Lopes S, Reik W, Fraser P. Active genes dynamically colocalize to shared sites of ongoing transcription. Nat Genet. 2004; 36: 1065 71. doi: $10.1038 / \mathrm{ng} 1423$.

34. Strongin DE, Groudine M, Politz JCR. Nucleolar tethering mediates pairing between the $\mathrm{IgH}$ and Myc loci. Nucleus. 2014; 5: 474-81. doi: 10.4161/nucl.36233.
35. Hakim O, Resch W, Yamane A, Klein I, Kieffer-Kwon K-R, Jankovic M, Oliveira T, Bothmer A, Voss TC, Ansarah-Sobrinho C, Mathe E, Liang G, Cobell J, et al. DNA damage defines sites of recurrent chromosomal translocations in B lymphocytes. Nature. 2012; 484: 69-74. doi: 10.1038/nature10909.

36. Rocha PP, Micsinai M, Kim JR, Hewitt SL, Souza PP, Trimarchi T, Strino F, Parisi F, Kluger Y, Skok JA. Close proximity to Igh is a contributing factor to AID-mediated translocations. Mol Cell. 2012; 47: 873-85. doi: 10.1016/j. molcel.2012.06.036.

37. Marquet M, Garot A, Bender S, Carrion C, Rouaud P, Lecardeur S, Denizot Y, Cogné M, Pinaud E. The E $\mu$ enhancer region influences $\mathrm{H}$ chain expression and $\mathrm{B}$ cell fate without impacting IgVH repertoire and immune response in vivo. J Immunol. 2014; 193: 1171-83. doi: 10.4049/jimmunol.1302868. 